\title{
Accuracy of Determining Underlying Cause of Death Based on Medical Mortality Data System \\ Keakuratan Penentuan Kode Underlying Cause Of Death Berdasarkan Medical Mortality Data System
}

\author{
Linda \\ Widyaningrum ${ }^{1)}$ \\ Tyas Kuntari ${ }^{2)}$
}

\author{
1,2)Program Studi D3 Rekam Medik dan Informasi \\ Kesehatan Fakultas Ilmu Kesehatan Universitas Duta \\ Bangsa Surakarta Jln KH Samanhudi No 93 Sondakan \\ Laweyan Surakata
}

\begin{abstract}
This article is retected from Jurnal Rekam Medis dan informasi Kesehatan Volume 1, Nomor 2 by editor due to publication ethics missconducted by author (simultaneously publication in other journal). Similar article can be found at URL:

http://ejournal.poltekkes-smg.ac.id/ojs/index.php/jrk/article/view/2832.

Artikel ini telah ditarik dari Jurnal Rekam Medis dan Informasi Kesehatan Volume, 1 Nomor 2 oleh editor dikarenakan kesalahan etika publikasi oleh penulis.. Artikel yang sama bisa ditemukan di URL :

http://ejournal.poltekkes-smg.ac.id/ojs/index.php/jrk/article/view/2832.
\end{abstract}

